\title{
THE NARCOTICS ABUSE TERM WEAKNESSES IN CRIMINAL LAW ENFORCEMENT OF INDONESIA
}

\author{
Elpina \\ Simalungun University \\ elpina.321@gmail.com \\ Mariah Sonanggok Purba \\ Simalungun University \\ mariapurba777@gmail.com
}

\begin{abstract}
A crime of narcotics abuse has experienced an alarming development, one of which is the increasing factor of narcotics abuse, one of which is the legal vacuum in law enforcement against drug abuse. The approach method used uses a normative juridical approach, the research results obtained are the weaknesses of narcotics criminal law enforcement include: (a) in the formulation of criminal sanctions, namely most of the criminal sanctions in Act No. 35 of 2009 are formulated cumutatively, in the formulation of the most cumulations are between imprisonment and sufficient fines. large, there are no special rules for corporations that do not pay fines, and no specific types of sanctions (criminal / action) are seen for corporations (b) related to the issue of criminal threats, namely: there are offenses that are given a special minimum criminal threat which is If there is a deviation from the Criminal Code system, there are no specific guidelines or regulations for the application of minimum penalties, and there are no specific criminal rules to implement the minimal system can be a problem if there is participation, trial, discourse, recidive, criminal mitigation, expiration, and so on.
\end{abstract}

Keywords: Criminal Law Enforcement; Narcotics Abuse; Weaknesses.

\section{A. INTRODUCTION}

The narcotics are substances or drugs that are very useful and necessary for the treatment of certain diseases. However, if it is misused or used not in accordance with the standard of treatment it can have very detrimental consequences for individuals or society, especially the younger generation. This will be more detrimental if, accompanied by the abuse and illicit trafficking of narcotics which can result in a greater danger to the life and cultural values of the nation which in turn can weaken national resilience. ${ }^{1}$ It can be said that, on the one hand, narcotics are drugs or substances that are useful in the fields of medicine, health care, and scientific development, but on the other hand they can cause dependency

1 Kaka Alvian Nasution, Himpunan Lengkap Undang-Undang Narkotika dan Psikotropika, Saufa, Yogyakarta, 2014, page.154 
which is very detrimental if used without strict and thorough control and supervision. $^{2}$

The development of narcotics crime as a transnational crime and organized crime has made Indonesia a country that has a drug emergency status. At first, narcotics were only used as a tool for religious ritual ceremonies, and besides that, they were also used for medicine. The first type of narcotics used was opium or commonly referred to as opium or opium. ${ }^{3}$

As a narcotics crime that has long been an enemy of the nation, now narcotics is very worrying for our nation and all nations in the world today. The production and circulation of massive narcotics are circulating in our society. The role of the narcotics mafia seems irresistible. Narcotics mafias have poisoned law enforcers as users and dealers in the Indonesian nation and various parts of the world, even though the entire nation is fighting this crime. People often hear statements about building a commitment or fighting together in combating narcotics in our country and around the world. ${ }^{4}$

In Indonesia, Narcotics is already at an alarming level and could threaten the country's security and sovereignty. Many cases are caused by narcotics cases. Areas that have never been touched by narcotics trafficking have gradually turned into centers for the circulation of narcotics. Likewise, children under 21 years of age who should still be taboo about this haram, have recently turned into addicts who are difficult to let go of their dependence. $^{5}$

The effects caused by narcotics have a profound effect on individuals and society. The effect of the personal effect of using natkotika is that it causes a decrease or change in consciousness, eliminates pain, and creates dependence on oneself. Meanwhile, the impact of losses on society is causing accidents, causing crimes, and other disturbances to society. ${ }^{6}$

Drug abuse and its consequences, both for abusers or users who are categorized as addicts and their social consequences, have long been a serious problem in various countries which have recently tended to be very dangerous, where the user will be dependent and will live in dependence on narcotic substances. ${ }^{7}$

The narcotics abuse has reached an alarming level, not only is the quantity of abuse increasing and widespread, but its users have also spread

2 Wenda Hartanto, The Law Enforcement Against Narcotic And Drug Crimes Impacting On Security And State Sovereignty In The Era Of International Free Trade, Jurnal Legislasi Indonesia, Vol. 14 N0. 01 March 2017, page.1-16

3 Kusno Adi, Diversi Sebagai Upaya Alternatif Penanggulangan Tindak Pidana Narkotika Oleh Anak, Cetakan Pertama, UMM Press, Malang, 2009, page. 3.

4 Anton Sudanto, Penerapan Hukum Pidana Narkotika di Indonesia, ADIL: Jurnal Hukum, Vol. 7 No.1 (2016), page.137-161

5 Dikdik M. Arief dan Elisatris Gultom, Urgensi Perlindungan Korban Kejahatan, PT. Raja Grafindo Persada, Jakarta, 2013, page. 101

6 Andri Winjaya Laksana, Tinjauan Hukum Pemidanaan Terhadap Pelaku Penyalahguna Narkotika Dengan Sistem Rehabilitasi, Jurnal Pembaharuan Hukum, Volume II No. 1 January - April 2015, page.74-85

7 Ibid. 
to almost all levels of society, from students to state officials who are involved in narcotics crime. The circulation of narcotics in Indonesia has an increasing trend, and what is very unfortunate that narcotics users are now starting to be carried out by government officials and law enforcers.

Many people say about the effect of narcotics on body and spirit. On the body, the effect can relieve pain, maintain stamina, and increase energy. In terms of spirituality, its effect can be calming, lull for a long time, increase the spirit. Some narcotics cause hallucinations, namely imaginary visions, fictional smells, and imaginary hearing. Not infrequently the influence brings great happiness and enjoyment. ${ }^{8}$

The birth of Act No. 35 of 2009 concerning Narcotics brings new nuances, paradigms, and hopes, because this Law has differences or specifications in the handling of narcotics cases. Act No. 35 of 2009 is no longer based solely on the imposition of penalties for narcotics abusers, which have so far been felt to be less effective in eradicating or reducing narcotics crimes.

Laws regulating narcotics and illegal drugs, namely Act No. 5 of 1997 concerning Psychotropics and Act No. 22 of 1997 concerning Narcotics which have been amended to Act No. 35 of 2009 use a penal system (criminal law)9 to tackle the dangers of narcotics abuse.

In Act No. 35 of 2009 as a means of penalties for tackling narcotics crime, the issue of narcotics offenses is regulated, which is fully stated in Chapter XV on Criminal Provisions which consists of 38 in the same article, such as the Criminal Code. In Act No. 35 of 2009, narcotics are divided into class I, group II and group III. Group I is seen as more dangerous than group II and group III. Likewise, group II is considered more dangerous than group III, so that the threat of punishment is graded according to that group.

The criminal threat in Act No. 35 Of 2009 is also graded according to the act and the amount of weight of each type. In addition, regarding the provisions of Article 113 paragraph (2), Article 114 paragraph (2), Article 115 paragraph (2), Article 116 paragraph (2), Article 118 paragraph (2), Article 119 paragraph (2), Article 121 paragraph (2) and Article 38 paragraph (2) of Act No. 35 Of 2009 states that there is a death penalty in addition to imprisonment and fines. The problem is how the mechanism is determined, and whether the imposition of the death penalty must also be accompanied by a fine, remembering that in a juridical normative manner, this cannot be justified. ${ }^{10}$

In relation to perpetrators of criminal acts, one of the issues that becomes the problem point in Act No. 35 of 2009 is the unclear definition and status of addicts, abusers and victims of narcotics abuse. Due to the

8 Andi Hamzah dan RM. Surachman, Kejahatan Narkotika Dan Psikotropika, Edisi Kesatu, Cetakan Pertama, Sinar Grafika, Jakarta, 1994, page. 4.

9 Barda Nawawi Arief, Kapita Selekta Hukum Pidana, Cetakan Ketiga, Citra Aditya Bakti, Bandung, 2013, page. 94.

10 Andi Hamzah dan Boedi Dwiyani Sri Marsita Goenanti, Kejahatan Narkotika \& Psikotropika, Cetakan Pertama, Universitas Trisakti, Jakarta, 2011, page. 33 dan 34. 
unclear definition and status, other arrangements have become biased and confusing. Of course in practice, this directly impacts narcotics users. One of them is in terms of providing medical and social rehabilitation for narcotics abusers and addicts.

The existence of juridical problems in Act No. 35 of 2009 will obstruct the efforts of law enforcers in preventing and eradicating narcotics crime, so that these juridical issues need to be formulated in the formulation policy for narcotics criminal sanctions in the future, which can fulfill legal objectives, namely legal certainty, benefit and justice.

The scope of criminal law policy actually covers a wide range of issues, namely covering the evaluation of the substance of the applicable criminal law (ius constitutum) for the renewal of the substance of criminal law in the future (ius constituendum), by applying this criminal law through the components of the criminal justice system, to find out whether the substance of the criminal law has fulfilled the sense of justice in society or vice versa. ${ }^{11}$

The purpose of writing in this study is to determine and analyze law enforcement against narcotics abuse by looking at legal weaknesses in the narcotics law in order to achieve the value of justice for narcotics abusers because the law must be certain, implemented impartially, seen as equality before the law.

\section{B. RESEARCH METHODS}

The approach method used in this legal research is normative juridical. Normative juridical research is research that is focused on examining the application of the rules or norms in positive law, ${ }^{12}$ which in this case is related to law enforcement against narcotics abuse perpetrators in the context of realizing justice. In research or study of normative legal science, activities to explain the law do not require the support of data or social facts, because normative law does not recognize social data or facts that are known only legal materials, so to explain law or to seek meaning and value The law only uses the concept of law and the steps taken are normative steps. ${ }^{13}$

\section{RESULT AND DISCUSSION}

\section{Weaknesses of Narcotics Abuse in Criminal Law Enforcement}

The development of narcotics in Indonesia is also due to organized international crimes from abroad. Criminal law itself should be that narcotics offenders are victims of criminal acts. ${ }^{14}$ This shows that the construction constructed by the formulation in Act No. 35 of 2009 is

11 Dahlan, Problematika Keadilan Dalam Penerapan Pidana Terhadap Penyalahguna Narkotika, Cetakan Pertama, Deepublish, Yogyakarta, 2017, page. 2 dan 3.

12 Jhonny Ibrahim, Teori dan Metodologi Penelitian Hukum Normatif, Bayumedia Malang, 2011, page. 295.

13 Bahder Johan Nasution, Metode Penelitian Ilmu Hukum, Mandar Maju, Bandung, 2008, page. 87.

14 Hafrida, Kebijakan Hukum Pidana Terhadap Pengguna Narkotika Sebagai Korban Bukan Pelaku Tindak Pidana, Jurnal Hukum Padjajaran, Vol.III No 1 (2016), page.173-191. 
that addicts and victims of narcotics abuse are given sanctions (medical rehabilitation and social rehabilitation), while narcotics abuse who are not addicts are given criminal sanctions.

There are several factors that can influence drug abuse, namely: First, the self-factor, which is a great curiosity to try, without realizing or thinking about the consequences at a later date. Second, social environmental factors, namely the influence arising from the social environment of the perpetrator, both school environment, association and others. At first maybe it was just a motive to want to year and try new things, then possible opportunities and supported by facilities and infrastructure. Third, personality factors: low self-esteem, emotionally unstable, mentally weak. ${ }^{15}$

The parameters of narcotics abuse victims in Act No. 35 Of 2009 are too narrow and difficult to prove by the suspect / defendant. Law enforcement officials use other regulations to determine the parameters of victims of narcotics abuse. These parameters are conditions of being caught in the act, evidence of narcotics is found for 1 (one) day use, positive use of narcotics, and there is no evidence of involvement in narcotics illicit trafficking. ${ }^{16}$

Narcotics abuse problem has been a difficult problem to eliminate and narcotics are included in extraordinary crimes or commonly called Extra Ordinary Crimes, ie acts where the criminal act must take precedence over other criminal cases and the criminal process must also be accelerated because Narcotics can be threatened and endanger Indonesian nation. ${ }^{17}$

Talking about the increasing prevalence of narcotics abuse cannot be separated from the existence of legal vacancies and weaknesses in law enforcement in Act No. 35 of 2009, namely:

a. Drug users are victims or perpetrators; ${ }^{18}$

One of the problems of Act No. 35 of 2009 is related to the position of narcotics users as perpetrators or as victims. It is difficult to separate between abusers and narcotics trafficking, but these cannot be equated and efforts to overcome them must also be distinguished.

Based on the objectives of Act No. 35 of 2009, and seeing the position of narcotics users, it can be seen that the eradication of narcotics is aimed at the illicit trafficking of narcotics, while efforts to prevent, protect and save the Indonesian nation from the misuse of narcotics, so it is necessary to regulate medical rehabilitation efforts.

15 Oksidelfa Yanto, Peranan Hakim Dalam Pemberantasan Tindak Pidana Narkoba Melalui Putusan Yang Berkeadilan, Jurnal Hukum dan Peradilan, Volume 6 No 2 2017, page.259278

16 Roni Gunawan Raja Gukguk, Nyoman Serikat Putra Jaya, Tindak Pidana Narkotika Sebagai Transnasional Organized Crime, Jurnal Pembangunan Hukum Indonesia, Volume 1, Nomor 3, Tahun 2019, page.337-351

17 Andri Winjaya Laksana, Social Analysis of Narcotics Abuse Prevention Women, Jurnal Pembaharuan Hukum, Volume VI No.3 September-December 2019, page.308-318

18 Dahlan, op.cit., page. 93-97. 
and social services for abusers and narcotics addicts (narcotics users).

Abusers who initially receive rehabilitation guarantees, however, by looking at the legality principle applied in Indonesia, in its implementation, narcotics users must face the risk of criminal threats as regulated in Article 127 of Act No. 35 of 2009. If narcotics users are considered to be criminals, then The question then is who is the victim of a crime committed by narcotics users, because in the criminal law there is no crime without a victim.

In order to answer the problem of narcotics users as perpetrators of criminal acts as well as victims, based on Article 103 of Act No. 35 of 2009, the Supreme Court issued a breakthrough by issuing SEMA Number 04 of 2010, in which the classification of criminal acts is determined as follows :

1) When the defendant was arrested by the National Police investigator and the National Narcotics Agency investigator, he was caught in the red;

2) At the time of being caught red-handed according to point a above, evidence of use of 1 (one) day is found;

3) A positive laboratory test letter using narcotics based on the request of the investigator;

4) Need a statement from a government psychiatrist / psychiatrist appointed by the judge;

5) It cannot be proven that the person concerned was involved in the trafficking of narcotics..

As a consequence, narcotics users are the perpetrators of criminal acts and at the same time as victims, the period of treatment and / or treatment for narcotics addicts as decided by the panel of judges adjudicating the case is counted as the period of serving a sentence, where the determination to undergo the treatment and treatment period is determined by experts. However, SEMA will be difficult to implement if other law enforcement officials do not have the same perspective on narcotics users.

Narcotics users are also citizens, whose rights are respected, protected and fulfilled by the state, both during legal proceedings and in health and social matters. In addition to the human rights inherent in every human being, both at the level of rights to health and rights when dealing with legal processes, specifically Act No. 35 of 2009 provides the following rights for users: ${ }^{19}$

b. Rehabilitation for narcotics users;

As stated in the objectives of Act No. 35 of 2009, in which there is a guarantee of rehabilitation efforts for narcotics users, where it is reaffirmed by Article 54 of Act No. 35 of 2009 that narcotics addicts and victims of narcotics abuse are obliged to undergo medical rehabilitation and social rehabilitation. 
Narcotics users can choose a rehabilitation place that has met the qualifications, and if narcotics users are under state supervision, then the state grants rehabilitation rights free of charge to narcotics users, where the financing can be taken from assets and assets confiscated by the state.

c. The right not to be prosecuted.

Act No. 35 of 2009 provides discretion on several matters so that narcotics users are not convicted, this discretion can be seen in Article 128 of Act No. 35 of 2009 which guarantees that they are not prosecuted for a crime with the following criteria:

1) Narcotics addicts who are not old enough and have been reported by their parents or guardians as in Article 55 paragraph (1);

2) Narcotics addicts who are old enough as referred to in Article 55 paragraph (2) who are undergoing medical rehabilitation for 2 (two) times the treatment period of a doctor at a hospital and / or medical rehabilitation institution appointed by the government.

d. The implementation of Act No. 35 Of 2009 depends on the implementing regulations;

As a form of Act No. 35 of 2009 which is an Administrative Law which regulates narcotics, several matters in Act No. 35 of 2009 must be rearranged by various implementing regulations. There are 10 provisions in Act No. 35 of 2009 which must be regulated in a Government Regulation, 2 provisions of Act No. 35 of 2009 which must be regulated in a presidential regulation, 17 provisions in Act No. 35 of 2009 which must be regulated in a regulation minister of health, 1 provision in Act No. 35 of 2009 which must be regulated in a social ministerial regulation, 2 provisions in Act No. 35 of 2009 which must be regulated by the Head of the Drug and Food Control Agency, and 2 provisions in Act No. 35 of 2009 which must be regulated by the Head of the National Narcotics Agency. Of the many implementing regulations mentioned above, several provisions have a direct impact on narcotics users.

Act No. 35 Of 2009 which was ratified and promulgated on October 12, 2009 and declared effective since it was promulgated, has given a time limit of 1 (one) year at the latest to stipulate implementing regulations, as regulated in Article 154 of Act No. 35 Of 2009. Although Article 152 states that all laws and regulations constitute implementing regulations of Act No. 22 Of 1997.

When Act No. 35 Of 2009 is promulgated, it is still valid as long as it is not contradictory and / or has not been replaced by a new regulation based on Act No. 35 Of 2009, however what must be considered is Act No. 35 Of 2009 is not a change / revision rule. from the previous law, but rather a regulation that replaces the previous narcotics regulation, so that the spirit and regulation in Act No. 35 of 2009 are different from the previous law, so it is important for stakeholders to prepare a new policy. - the implementing regulations or at least correcting the previous implementing regulations whether 
they are in accordance with the spirit of Act No. 35 Of 2009, so that implementation does not encounter any obstacles.

The absence of visible efforts to formulate implementing regulations from Act No. 35 of 2009, especially for the benefit of users, creates problems because eradication efforts run faster than prevention and recovery efforts.

e. The overlapping articles on the punishment of narcotics users; ${ }^{20}$

Narcotics users who still get narcotics against the law, then there are several actions taken by the narcotics user, namely buying, controlling, storing, or possessing which they ultimately use themselves.

Act No. 35 of 2009 does not provide a clear distinction between criminal offenses in Article 127 and other criminal offenses contained in Act No. 35 of 2009, in which narcotics users who get narcotics illegally must fulfill the element of control, possessing , keeping, or buying narcotics, which is also regulated as a separate criminal offense in Act No. 35 of 2009, and there is no regulating the attempted use of narcotics for himself.

In practice, law enforcement officials associate (including / juncto) the criminal offense of narcotics users with the criminal offense of possession, possession, storage or purchase of narcotics without rights and against the law where the legal threat is more than 5 years in prison and in some cases more than 9 years. imprisonment, so that based on Article 21 paragraph (4) letter a of the Criminal Procedure Code, narcotics users can be detained, and if they are subject to criminal provisions with a threat of more than 9 (nine) years, then based on Article 29 of the Criminal Procedure Code, the period of detention can be added up to 60 (sixty). day.

Apart from being threatened with criminal sanctions as stipulated in Article 127 of Act No. 35 of 2009, narcotics users can also be subject to various other criminal provisions in Act No. 35 of 2009 as long as the elements of controlling, possessing, storing, or buying narcotics without rights are fulfilled. and against the law where it has a higher criminal sanction and there is no option for the judge to issue a rehabilitation decision without a prison sentence because of the minimum limit of convictions in the offense.

f. There is no clear expiration date for narcotics users; ${ }^{21}$

Act No. 35 Of 2009 does not provide a clear expiration for the criminal acts that can be imposed on narcotics users. For former narcotics users who later tell their experiences of using narcotics in front of a large crowd, and narcotics users who are undergoing the rehabilitation process on their own (not based on a judge's decision) can be subject to punishment for past actions (buying, using, controlling or storing). narcotics without rights and against the law) may at any time be subject to punishment. 
The non-regulation of exemption from time periods for narcotics users who are or are already in the stage of ex-narcotics users has resulted in law enforcement officials that determine the user as a wanted list for people to supervise narcotics users where it is not closed to be carried out in rehabilitation places.

g. Drug users are vulnerable to torture and cruel treatment or punishment; $; 2$

Even though Indonesia has ratified the convention against torture and cruel treatment, the criminal procedure law in Indonesia is still vulnerable to practices of torture and cruel treatment, especially detained narcotics users. Manfred Nowak, a special reporter for the United Nations Unit, argued that for torture and cruel treatment, the Indonesian government had recommended to limit the time for arrest and detention, but Act No. 35 of 2009 ignored these recommendations by giving authority to BNN investigators to be able to arrest narcotics users for 3 days and can be extended 3 days. Act No. 35 Of 2009 also does not provide any arrangements regarding rehabilitation guarantees for narcotics users during the legal process. Rehabilitation is only obtained after obtaining a verdict / ruling on the judge examining the case.

The long period of time for arrest and detention, then without guaranteed rehabilitation results in narcotics users experiencing worse conditions compared to other criminal offenders, so they tend to have the potential for cruel forms of treatment and punishment.

h. The difficulty of implementing the Supreme Court Circular (SEMA) Number 04 of 2010.

Although the Supreme Court issued SEMA, it cannot intervene with other law enforcers (investigators and public prosecutors). SEMA implementation will not be able to run if:

1) Investigations emphasize the involvement of the suspect in the trafficking of narcotics and do not care whether the suspect is a drug user or not;

2) The investigator does not want to cooperate to ask for a laboratory test statement to see if the suspect is positive for using narcotics;

3) The public prosecutor charged a single charge of possession of narcotics even though it was proven that the defendant was positive for using narcotics, thus leading the judge to convict the possession of narcotics for non narcotics users;

4) The public prosecutor does not want to accept experts who are asked by the judge to assess the level of addiction of narcotics users, thus hampering the rehabilitation decision;

5) Narcotics users who are legally blind, thus denying narcotics that are actually used for their own interests, which are ultimately punished for abuse, possession, storage or purchase. 
Act No. 35 of 2009 does not explicitly regulate the threat of punishment for narcotics offenders. The existence of a maximum limit and a minimum limit gives flexibility to the judge to impose a sentence. This is what causes different sentences or causes disparity in the imposition of criminals. One of the causes of disparities in the imposition of crimes is basically starting from the law itself, where the law opens up opportunities for crimes due to the existence of minimum and maximum punishments, so that judges are free to move to impose crimes which he thinks are appropriate. With the existence of minimum and maximum limits in Act No. 35 of 2009, in practice, law enforcers, both public prosecutors, are free to make criminal charges against narcotics criminals and judges in imposing criminal decisions.

Drug users are a form of crime in society. Use of Narcotics is a Crime Without Victim because in essence users become themselves as victims. ${ }^{23}$ In the framework of law enforcement and justice, the court has an important role in which the judge, as a person who carries out activities in the field of justice, must equip himself with values that develop and live in society regarding the meaning of justice in addition to mastering the norms of written law.

\section{Criminal Law Reforms for Narcotics Abusers}

The problem of narcotics abuse is not only a problem that needs attention for the Indonesian state, but also for the international community, that entering the 20th century the international attention to the problem of narcotics is increasing, one of which can be seen through the Single Convention on Narcotic Drugs in $1961^{24}$. The policy to tackle narcotics crime is an integral part of protecting society from the dangers of narcotics, and the long-term goal is to achieve social welfare, so that the main objective of criminal policy is protection to achieve community welfare to achieve justice.

Regarding the ideal between rehabilitation and imprisonment, each action has strengths and weaknesses that are deemed crucial. On the one hand, rehabilitation has the advantage of being a place for humane recovery for addicts and victims of narcotics abuse, but it has a weakness in its technical field and a place where narcotics mafias hide from legal traps. On the other hand, imprisonment has the advantage of providing a punishment that is appropriate for destroying the nation, but the negative side is that it will enlarge the narcotics network if the perpetrators are mixed in prison. ${ }^{25}$

23 Muhammad Asyharuddin, Baharuddin Badaru, Muhammad Kamal Hidjaz, Analisis Sanksi Pidana Terhadap Pelaku Tindak Pidana Narkotika, Pleno Jure, Vol 9, No, 1, April 2020, page.58-71

24 Andika Saputra, Sabar Slamet, Upaya Penanggulangan Peredaran dan Penyalahgunaan Narkoba di Kabupaten Sukoharjo, Recidive, Volume 8 No. 1, January-April 2019, page.55-62

25 Ratna WP, Aspek Pidana Penyalahgunaan Narkotika, Rehabilitasi Versus Penjara (Menyoroti Pasal 127 UU No. 35 Tahun 2009), Cetakan Pertama, Legality, Yogyakarta, 2017, page. 155 
The shift of punishment from corporal punishment to action punishment is a process of depenalization because developments or shifts in legal values in society affect the development of legal values in criminal law norms. The act is still a disgraceful act, but it does not deserve to be subjected to heavy criminal sanctions, it is more appropriate to be subject to minor criminal sanctions or actions. As for the reasons for determining depenalization of addicts and victims of narcotics, because they are considered sick people, so they need to receive treatment by providing therapy or drugs to recover.

For victims of narcotics abuse, in fact they do not realize that what has been done is caused by the persuasion of other people, so they need to be saved by being rehabilitated, so that they do not get caught up in the severity of the effects of narcotics. ${ }^{26}$

That the existence of Act No. 35 of 2009 is to create order and improve the condition of society to be even better, as explained in the theory of community justice, which measures justice as a legal goal, namely a good society and the role of law to actualize justice. . However, the unclear definition and status of addicts, abusers, and victims of narcotics abuse makes other arrangements biased and confusing, and in practice, this directly impacts narcotics users, one of which is the provision of medical rehabilitation. and social services for abusers and narcotics addicts.

Regarding weaknesses in the policy of criminal sanctions formulation for narcotics criminal offenders, it is necessary to renew the policy for the formulation of criminal sanctions for the future, especially articles that are ambiguous, namely articles that regulate narcotics users.

a. Draft on Criminal Code 2017 (RUU KUHP 2017)

In the Draft Criminal Code 2017, regarding the criminal act of narcotics, the provisions are regulated in Chapter XVII concerning the Crime of Misuse of Narcotics and Psychotropics from Article 507Article 52. Criminal sanctions in the Draft Criminal Code 2017 for narcotics crimes are in the form of imprisonment and fines.

b. Reconstruction of several articles in Act No. 35 of 2009;

As it is known, Act No. 35 of 2009 has regulated criminal penalties for narcotics offenders. In Article 111 of Act No. 35 of 2009 it regulates the control of narcotics group I in the form of plants and in Article 112 of Act No. 35 of 2009 regulates the control of narcotics in the form of non-plants. Especially for users or perpetrators of narcotics abuse for themselves, Act No. 35 of 2009 has regulated it in Article 127 paragraph (1), paragraph (2), and paragraph (3).

Legal reconstruction of Articles 111 and 112 of Act No. 35 Of 2009 which use the words "control, keep, possess" which allows any narcotics abuser to be entangled with the provisions of the two Articles, as well as the unclear provisions of Article 127 of Act No. 35 of 2009 concerning in any circumstances and the criteria for a person to be said to be a narcotics abuser resulted in many irregularities in

26 Dahlan op.cit., page. 81 . 
the application of Article 127 of Act No. 35 of 2009, so that the person who should be convicted as a user is even subject to an article with the category of possession or control which results in imposing a sentence that is not right on target where a person should be rehabilitated in order to be free from dependence on narcotics, but instead is sentenced to imprisonment with a minimum sentence of 4 (four) years.

A user who is caught while in possession of narcotics will be ensnared with the provisions of Article 111 and Article 112 of Act No. 35 Of 2009, which carries a minimum penalty of 4 (four) years in prison. Thus, Article 111, Article 112 and Article 114 of Act No. 35 Of 2009 need to be specifically for dealers and not for abusers (addicts). As well as in the case of narcotics abusers for themselves fulfilling the qualification elements of narcotics crime as regulated in another article, then it must be assessed from the inner attitude / mens rea of the perpetrator, as long as his inner attitude is to be used alone for his dependency needs, the judge must decided to apply sanctions in the form of medical rehabilitation and social rehabilitation. ${ }^{27}$

Placing narcotics abuse offenders who are addicted or who have the effects of severe drug dependence by taking action to imprison them in prison is very inappropriate and contrary to the principle of benefit which is one of the objectives of the law because those who are in a state of dependence really need to be given treatment and / or treatment, it is not appropriate if it is carried out in a prison, given the condition of the prison which is currently inadequate for the treatment and treatment process for narcotic addicts inmates. ${ }^{28}$

\section{CONCLUSION}

The weaknesses of the policy formulation of criminal sanctions against perpetrators of narcotics crime in Act No. 35 of 2009 concerning Narcotics, including: (a) in the formulation of criminal sanctions, namely most of the criminal sanctions in Act No. 35 of 2009 are formulated in a manner cumutative, in the formulation of the most amount of cumulation is between imprisonment and a fairly large fine, there are no special rules for corporations that do not pay fines, and there are no specific types of sanctions (criminal/action) for the corporation (b) related to the problem. criminal threats, namely: there are offenses that have been given a special minimum criminal threat which constitutes a deviation from the Criminal Code system, there are no guidelines or regulations for the application of minimum criminality that are specific, and there are no specific criminal rules to implement the system at least it can be a problem if there is "participation, trial, discourse, recidive, mitigation/penalties, expiration, and

27 Ibid.

28 Mustating Dg Maroa, Penegakan Hukum Dalam Penanggulangan Tindak Pidana Penyalahgunaan Narkotika Di Kabupaten Banggai, Jurnal Yustisiabel, Volume I Nomor I April 2017, page.56-68 
so on". In addition to these problems there are other problems, namely regarding: the position of narcotics users as perpetrators or victims, implementation of Act No. 35 of 2009 depending on the implementing regulations, overlapping articles of punishment for narcotics users, there is no clear expiration limit for narcotics users, Narcotics users are vulnerable to torture and cruel treatment or punishment, and the difficulty of implementing SEMA Number 04 of 2010.

\section{BIBLIOGRAPHY}

\section{Books:}

Andi Hamzah dan RM. Surachman, 1994, Kejahatan Narkotika Dan Psikotropika, Edisi Kesatu, Cetakan Pertama, Sinar Grafika, Jakarta;

Andi Hamzah dan Boedi Dwiyani Sri Marsita Goenanti, 2011, Kejahatan Narkotika \& Psikotropika, Cetakan Pertama, Universitas Trisakti, Jakarta;

Bahder Johan Nasution, 2008, Metode Penelitian IImu Hukum, Mandar Maju, Bandung;

Barda Nawawi Arief, 2013, Kapita Selekta Hukum Pidana, Cetakan Ketiga, Citra Aditya Bakti, Bandung;

Dahlan, 2017, Problematika Keadilan Dalam Penerapan Pidana Terhadap Penyalahguna Narkotika, Cetakan Pertama, Deepublish, Yogyakarta;

Dikdik M. Arief dan Elisatris Gultom, 2013, Urgensi Perlindungan Korban Kejahatan, PT. Raja Grafindo Persada, Jakarta;

Jhonny Ibrahim, 2011, Teori dan Metodologi Penelitian Hukum Normatif, Bayumedia Malang;

Kaka Alvian Nasution, 2014, Himpunan Lengkap Undang-Undang Narkotika dan Psikotropika, Saufa, Yogyakarta;

Kusno Adi, 2009, Diversi Sebagai Upaya Alternatif Penanggulangan Tindak Pidana Narkotika Oleh Anak, Cetakan Pertama, UMM Press, Malang;

Ratna WP, 2017, Aspek Pidana Penyalahgunaan Narkotika, Rehabilitasi Versus Penjara (Menyoroti Pasal 127 UU No. 35 Tahun 2009), Cetakan Pertama, Legality, Yogyakarta;

\section{Journals:}

Andika Saputra, Sabar Slamet, Upaya Penanggulangan Peredaran dan Penyalahgunaan Narkoba di Kabupaten Sukoharjo, Recidive, Volume 8 No. 1, January-April 2019;

Andri Winjaya Laksana, Tinjauan Hukum Pemidanaan Terhadap Pelaku Penyalahguna Narkotika Dengan Sistem Rehabilitasi, Jurnal Pembaharuan Hukum, Volume II No. 1 January-April 2015; 
Andri Winjaya Laksana, Social Analysis of Narcotics Abuse Prevention Women, Jurnal Pembaharuan Hukum, Volume VI No.3 September-December 2019;

Anton Sudanto, Penerapan Hukum Pidana Narkotika di Indonesia, ADIL: Jurnal Hukum, Vol. 7 No.1 (2016);

Hafrida, Kebijakan Hukum Pidana Terhadap Pengguna Narkotika Sebagai Korban Bukan Pelaku Tindak Pidana, Jurnal Hukum Padjajaran, Vol.III No 1 (2016);

Muhammad Asyharuddin, Baharuddin Badaru, Muhammad Kamal Hidjaz, Analisis Sanksi Pidana Terhadap Pelaku Tindak Pidana Narkotika, Pleno Jure, Vol 9, No, 1, April 2020;

Mustating Dg Maroa, Penegakan Hukum Dalam Penanggulangan Tindak Pidana Penyalahgunaan Narkotika Di Kabupaten Banggai, Jurnal Yustisiabel, Volume I Nomor I April 2017;

Oksidelfa Yanto, Peranan Hakim Dalam Pemberantasan Tindak Pidana Narkoba Melalui Putusan Yang Berkeadilan, Jurnal Hukum dan Peradilan, Volume 6 No 2 2017;

Roni Gunawan Raja Gukguk, Nyoman Serikat Putra Jaya, Tindak Pidana Narkotika Sebagai Transnasional Organized Crime, Jurnal Pembangunan Hukum Indonesia, Volume 1, Nomor 3, Tahun 2019;

Wenda Hartanto, The Law Enforcement Against Narcotic And Drug Crimes Impacting On Security And State Sovereignty In The Era Of International Free Trade, Jurnal Legislasi Indonesia, Vol. 14 N0. 01 March 2017; 